\title{
CHROMIUM-BASED OXIDATION-RESISTANT COATINGS FOR THE PROTECTION OF ENGINE VALVES IN AUTOMOTIVE VEHICLES
}

\author{
PREVLEKE NA OSNOVI KROMA, ODPORNE PROTI OKSIDACIJI, \\ KOT ZAŠČITA VENTILOV MOTORJA PRI AVTOMOBILIH
}

\author{
Monika Drożdż, Karol Kyziol, Zbigniew Grzesik \\ AGH University of Science and Technology, Faculty of Materials Science and Technology, Department of Physical Chemistry and Modelling, \\ Al. A. Mickiewicza 30, 30-059 Krakow, Poland \\ grzesik@agh.edu.pl
}

Prejem rokopisa - received: 2016-07-12; sprejem za objavo - accepted for publication: 2016-10-07

doi:10.17222/mit.2016.151

\begin{abstract}
The influence of a thin chromium layer $(1 \mu \mathrm{m})$ sputter-deposited on the surfaces of four valve steels (X33CrNiMn23-8, $\mathrm{X} 50 \mathrm{CrMnNiNbN} 21-9, \mathrm{X} 53 \mathrm{CrMnNiN} 20-8$ and $\mathrm{X} 55 \mathrm{CrMnNiN} 20-8$ ) was studied at $900{ }^{\circ} \mathrm{C}$ under isothermal and thermal-shock conditions. It was determined that the oxidation resistance of coated steels is much better than that of uncoated ones. This situation is a result of the formation of highly protective $\mathrm{Cr}_{2} \mathrm{O}_{3}$ scales on the surfaces of coated materials. It was also demonstrated that a positive effect of a chromium addition on the oxidation resistance of the investigated steels is observed during a much longer period than the lifetime of a chromium coating.

Keywords: valve steels, chromium layer, oxidation, isothermal conditions, thermal shocks
\end{abstract}

Preučevan je bil vpliv tanke plasti kroma $(1 \mu \mathrm{m})$, ki se je med pršenjem odlagal na površini štirih ventilov iz jekel: X33CrNiMn23-8, X50CrMnNiNbN21-9, X53CrMnNiN20-8 in X55CrMnNiN20-8, in sicer pri $900{ }^{\circ} \mathrm{C}$, v izotermičnih pogojih in s toplotnimi šoki. Ugotovljeno je bilo, da je odpornost na oksidacijo pri premazanih jeklih veliko boljša kot pri jeklih brez prevlek. To stanje je posledica tvorbe visokozaščitnih $\mathrm{Cr}_{2} \mathrm{O}_{3}$ lestvic na površinah prevlečenih materialov. Dokazano je bilo tudi, da je pozitiven učinek proti oksidaciji, zaradi dodatka kroma, mogoče opaziti v mnogo daljšem časovnem obdobju, kot v celotni življenjski dobi preiskovanih jekel.

Ključne besede: jekleni ventili, plast kroma, oksidacija, izotermični pogoji, termični šoki

\section{INTRODUCTION}

Engine valves in automotive vehicles work in very severe conditions due to rather high temperatures (of up to about $900{ }^{\circ} \mathrm{C}$ ), aggressive atmosphere of combustion gases and, in particular, rapid temperature changes, described in literature as thermal shocks. ${ }^{1}$ Under thermalshock conditions, high thermal stresses are generated at the interface between a valve and the oxidation-product layer, called the scale, due to different thermal-expansion coefficients of both materials. ${ }^{2,3}$ Consequently, during the heating and cooling of an automobile engine, cracking and spalling of the scale are observed, which considerably lower the corrosion resistance of the valves. Thus, in addition to the protective properties of the scale, its adherence to the substrate constitutes the most important factor for determining the corrosion resistance of an oxidized material under thermal-shock conditions. ${ }^{3-6}$ Recently, problems with corrosion degradation of engine valves in automobiles have become more and more important as a result of an increase in the working temperature in modern car engines and the application of alternative fuels like biofuels, liquid petroleum gas (LPG), compressed natural gas (CNG), etc. - the combustion products that are very aggressive..$^{7-13}$ As a consequence, protection of engine valves against hightemperature corrosion is urgently needed.

Among several protection methods for engine valves, the most promising one seems to be the application of protective coatings. ${ }^{14-16}$ In this case, the main idea is the creation of such conditions, under which selective oxidation of chromium or aluminum takes place because oxides of both these metals $\left(\mathrm{Cr}_{2} \mathrm{O}_{3}\right.$ and $\left.\mathrm{Al}_{2} \mathrm{O}_{3}\right)$ show excellent corrosion protection. The most frequently utilized protective coatings against high-temperature oxidation are thermal-barrier coatings (TBC). ${ }^{15}$ The high efficiency of such coatings in protecting valve steels was proved experimentally by us many years ago. ${ }^{17} \mathrm{Un}$ fortunately, TBC coatings were never used in the mass production in the automobile industry due to economic reasons, i.e., relatively high costs of their production. Consequently, we designed a new generation of inexpensive coatings, which can be potentially used for the protection of engine valves. It was shown that such coatings, in contrast to the rather thick and, thereby, expensive TBC corrosion-resistant coatings, contain a very small amount of chromium, which is, however, high enough to form a continuous layer of highly-protective $\mathrm{Cr}_{2} \mathrm{O}_{3}$ oxide during the initial stage of oxidation. ${ }^{18}$ 
The stability and further growth of this chromium oxide layer is a result of outward chromium diffusion from the protected material. Thus, the proposed novel coatings only play the role of the initiator for the formation of the $\mathrm{Cr}_{2} \mathrm{O}_{3}$ layer, after which they disappear relatively fast. In spite of this fact, a better oxidation resistance of valve steels covered with thin novel coatings is observed during a much longer period than the lifetime of these coatings under isothermal conditions. Consequently, the obtained preliminary results strongly support the idea of tailoring a new generation of inexpensive coatings for mass application in protecting engine valves against high-temperature corrosion. It should be noted, however, that the beneficial influence of the discussed novel coatings on the oxidation behavior of valve steels has been investigated up to now only for two steels (X33CrNiMn23-8 and X50CrMnNiNbN21-9) under isothermal conditions. ${ }^{18}$

Thus, the aim of this work was to study the oxidation behavior under both isothermal and thermal-shock conditions of four valve steels, X33CrNiMn23-8 (X33), X50CrMnNiNbN21-9 (X50), X53CrMnNiN20-8 (X53) and $\mathrm{X} 55 \mathrm{CrMnNiN} 20-8$ (X55), covered with novel coatings, utilized at present for the production of engine valves; the obtained results are reported in the present paper.

\section{EXPERIMENTAL PART}

Four chromium-nickel steels (X33, X50, X53 and $\mathrm{X} 55$ ), utilized for the engine-valve production, were used for the investigations of this work. The chemical compositions of these steels are presented in Table 1.

The samples for oxidation studies were obtained from the rods of the four above-mentioned steels with diameters of about $20 \mathrm{~mm}$. These rods were cut into discs with thicknesses of approximately $1 \mathrm{~mm}$. Next, disc-shaped samples were grinded with emery papers (up to 800 gradation $\mathrm{SiC}$ paper) and finally polished using $0.25 \mu \mathrm{m}$ diamond pastes to obtain mirror-like surfaces. Some of these samples were covered with a chromium layer with a $1-\mu \mathrm{m}$ thickness. Chromium coatings were deposited via magnetron sputtering in an argon atmosphere. A vacuum apparatus of the Elettorava S.p.A. company that operates at a constant current $(2 \mathrm{~kW})$, power supplier of the Dora company, was used in this procedure.

The substrates were mounted onto a two-fold rotary holder using a nickel-chromium wire. The chromium target was a cathode with a 25.4-mm diameter, 2-mm thickness and $99.95 \%$ purity. After the air was evacuated to a pressure of below $10^{-3} \mathrm{~Pa}$, argon-ion cleaning was conducted with the help of three ion guns. The energy of the argon ions was about $4 \mathrm{keV}$, the sample bias was changed from $0 \mathrm{kV}$ to $2 \mathrm{kV}$ and the cleaning time was 30 min. Magnetron sputtering of the pure chromium target was started immediately after the argon-ion cleaning. The argon pressure during the deposition was 0.39 Pa. The magnetron-sputtering process was carried out under $640 \mathrm{~V}$ and $1 \mathrm{~A}$. The sample bias of the modulated DC current during the deposition was $50 \mathrm{~V} / 0.03 \mathrm{~A}$. The sputtering time was $40 \mathrm{~min}$.

The oxidation kinetics of the coated and uncoated specimens was carried out in air at $900{ }^{\circ} \mathrm{C}$ in a microthermogravimetric apparatus. This apparatus is equipped with an electronic microbalance enabling the determination of weight gains of the oxidizing steel samples with an accuracy of the order of $10^{-6} \mathrm{~g} .{ }^{17}$ On the other hand, the corrosion tests under the thermal-shock conditions were carried out in the experimental set, described elsewhere. ${ }^{19}$ These experiments consisted of determining the mass changes of corroded samples as a function of the number of thermal shocks. Thus, a given sample was rapidly heated from room temperature up to $900{ }^{\circ} \mathrm{C}$ and after the heat treatment at this temperature for two hours, it was cooled down rapidly (quenching) to room temperature. The duration of the heating time was approximately one min. The cooling time, in turn (quenching), took place in combustion gases passing through the reaction chamber for about two min. The temperature in both types of tests, equal to $900{ }^{\circ} \mathrm{C}$, represents the highest possible temperature occurring in modern automobile engines.

The phase composition of the oxidation products (scales) was studied with X-ray diffraction (XRD), while the morphology and chemical composition of the reaction products were investigated using scanning electron microscopy (SEM) combined with energy-dispersive $\mathrm{X}$-ray analysis (EDX).

\section{RESULTS AND DISCUSSION}

The results obtained during the oxidation studies under isothermal conditions of the coated and uncoated specimens are presented in Figure 1. From this figure, it follows that the oxidation rate of all the valve steels coated with a chromium thin layer is lower than the rate observed in the case of the uncoated materials. The best

Table 1: Chemical compositions (in mass fractions, w/\%) of X33, X50, X53 and X55 valve steels

\begin{tabular}{|l|c|c|c|c|c|c|c|c|c|c|c|c|}
\hline \multicolumn{1}{|c|}{ Type of steel } & $\mathrm{C}$ & $\mathrm{Mn}$ & $\mathrm{Si}$ & $\mathrm{Cr}$ & $\mathrm{Ni}$ & $\mathrm{N}$ & $\mathrm{W}$ & $\mathrm{Nb}$ & $\mathrm{S}$ & $\mathrm{P}$ & $\mathrm{Mo}$ & $\mathrm{Fe}$ \\
\hline X33CrNiMn23-8 & 0.35 & 3.30 & 0.63 & 23.40 & 7.80 & 0.28 & 0.02 & - & $<0.005$ & 0.014 & 0.11 & bal. \\
\hline X50CrMnNiNbN21-9 & 0.54 & 7.61 & 0.30 & 19.88 & 3.64 & 0.44 & 0.86 & 2.05 & 0.001 & 0.031 & - & bal. \\
\hline X53CrMnNiN20-8 & 0.53 & 10.30 & 0.30 & 20.50 & 4.10 & 0.41 & - & - & $<0.005$ & 0.040 & 0.12 & bal. \\
\hline X55CrMnNiN20-8 & 0.55 & 8.18 & 0.17 & 20.00 & 2.30 & 0.38 & - & - & $<0.005$ & 0.030 & 0.11 & bal. \\
\hline
\end{tabular}




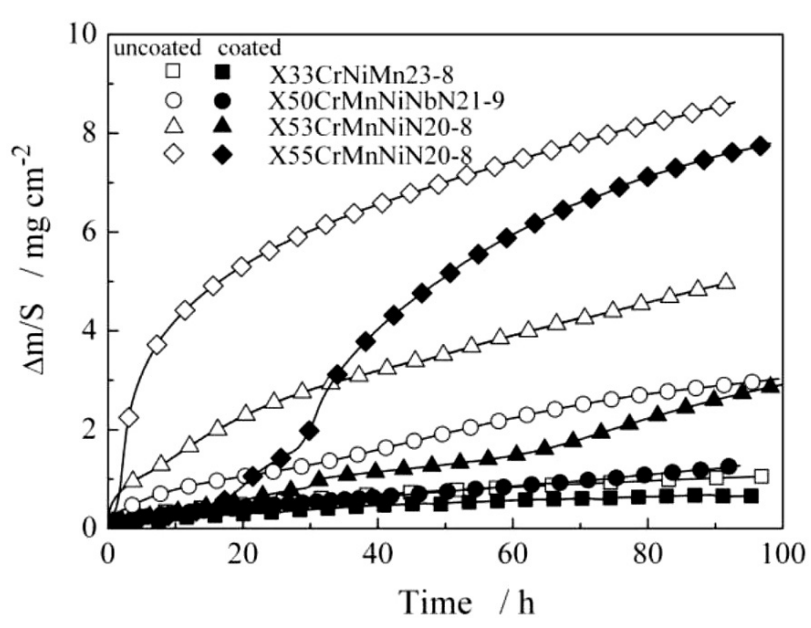

Figure 1: Comparison of the oxidation kinetics of four coated (black points) and uncoated (white points) valve steels at $T=900{ }^{\circ} \mathrm{C}$ in air, presented with a linear plot of coordinates $(\Delta \mathrm{m} / \mathrm{S}$ - weight changes of an oxidized sample per unit surface area)

oxidation resistance was observed in the case of the coated X33 steel. However, the beneficial effect of chromium is relatively small because the oxidation rate of this steel is very low compared to the other steels under discussion. This situation is a result of the fact that the X33 steel has the highest chromium content (Table 1), which, after selective oxidation, can form a highly protective, continuous $\mathrm{Cr}_{2} \mathrm{O}_{3}$ chromium-oxide layer. ${ }^{7,8}$ Thus, the high resistance of the X33 steel can be further increased to a relatively low degree by applying a thin chromium layer.

In the case of all the other steels with lower chromium contents, the deposition of a thin chromium layer considerably increases their oxidation resistance. It should be noted, however, that this effect is visible for the X55 steel only in the initial stages of the reaction, which denotes that the applied chromium layer does not exhibit sufficient thickness to ensure a full protection under the applied experimental conditions. It is very interesting that the positive effect of chromium on the oxidation resistance of the investigated steels is observed during a much longer period than the lifetime of the chromium coating. In the case of all the coated steels, the chromium layer can be observed for up to about $15 \mathrm{~h}$, after which it disappears. However, in spite of the lack of the metallic chromium layer on the surface of the investigated steels, the oxidation resistances of the studied steels remained at the same level because the character of kinetic curves virtually remained unchanged.

The results of the thermal-shock experiments, obtained for all the investigated steels covered with a thin chromium layer, compared with the analogous results reported for the uncovered materials are presented in Figure 2. The interpretation of these results is as follows. If a given specimen gradually loses its mass with consecutive thermal shocks, it denotes that the scale cracks and spalls off from the surface of the investigated material due to thermal stresses. It means that the higher the mass losses of a given sample as a function of time, the poorer are the protective properties of the growing scale. On the other hand, if the mass of a sample virtually remains unchanged with a number of shocks (or increases only very slightly), it means that, in spite of the thermal stresses, the scale does not crack and spall off from the surface of the specimen and, consequently, satisfactorily protects the material against high-temperature corrosion.

From the comparison presented in Figure 2, it follows that the adherence of the scale growing on the surface of the X33 steel is very good because the mass changes of the investigated sample with a number of thermal shocks are virtually not observed. The thin chromium layer deposited on this steel has, in practice, no influence on its oxidation resistance under the thermal-shock conditions. On the other hand, the beneficial effect of the chromium deposition on the X50 and X53 steels is clearly visible. The masses of both of these uncoated steels gradually decrease during the oxidation, from the beginning of the reaction to the completion of 120 thermal shocks, and the total mass losses of the oxidized samples are about $100 \mathrm{mg} / \mathrm{cm}^{2}$. On the other hand, the chromium-coated X50 steel starts to lose its mass after about 100 shocks and the total mass change after the completion of the experiment ( 250 shocks) is 40 $\mathrm{mg} / \mathrm{cm}^{2}$. This means that the cracking and spalling of the scale are only fragmentary and, consequently, this coated steel is rather well protected by the oxidation product. In other words, these results indicate that the adherence of the scale to the steel surface is rather high. Therefore, the scale protects the material, to some extent, against high-temperature corrosion under severe thermal-shock conditions.

The coated X53 steel behaves much better than the uncoated one. However, their resistance against oxidation under thermal-shock conditions is poorer than that observed for the coated X50 steel. The coated X53 steel starts to lose its mass after 40 thermal shocks and the

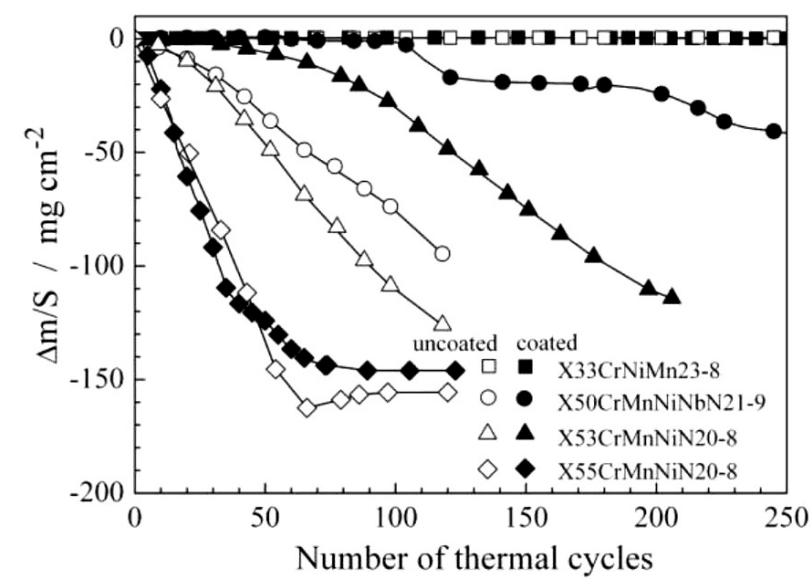

Figure 2: Results of thermal shocks for four valve steels with and without a chromium coating 
total mass loss after 200 shocks is comparable to that observed for the uncoated steel after 100 shocks (110 $\mathrm{mg} / \mathrm{cm}^{2}$ ). These results may then be considered as an important proof of a good protective effect of the applied thin chromium coating in the case of both steels.

The poorest effects were obtained in the case of the X55 steel. As can be seen in Figure 2, no influence of the thin chromium layer on the oxidation resistance of the X55 steel under the thermal-shock conditions was observed. The chromium content in this steel (Table 1) is not high enough to form a highly protective chromiumoxide layer during the oxidation. As a consequence, the X55 steel corrodes very fast in all the experimental conditions that have been applied up to now. ${ }^{7,8}$ The obtained results indicate that the relatively thin chromium coating deposited on the surface of the X55 steel does not create conditions sufficient to enable the growth of a compact and protective layer of chromium oxide. In the case of this steel, a thicker chromium layer should probably be applied.

The results of the oxidation studies of the four valve steels covered with a thin chromium layer, carried out under isothermal and thermal-shock conditions, generally confirm the beneficial influence of a chromium addition on the oxidation resistance of the investigated
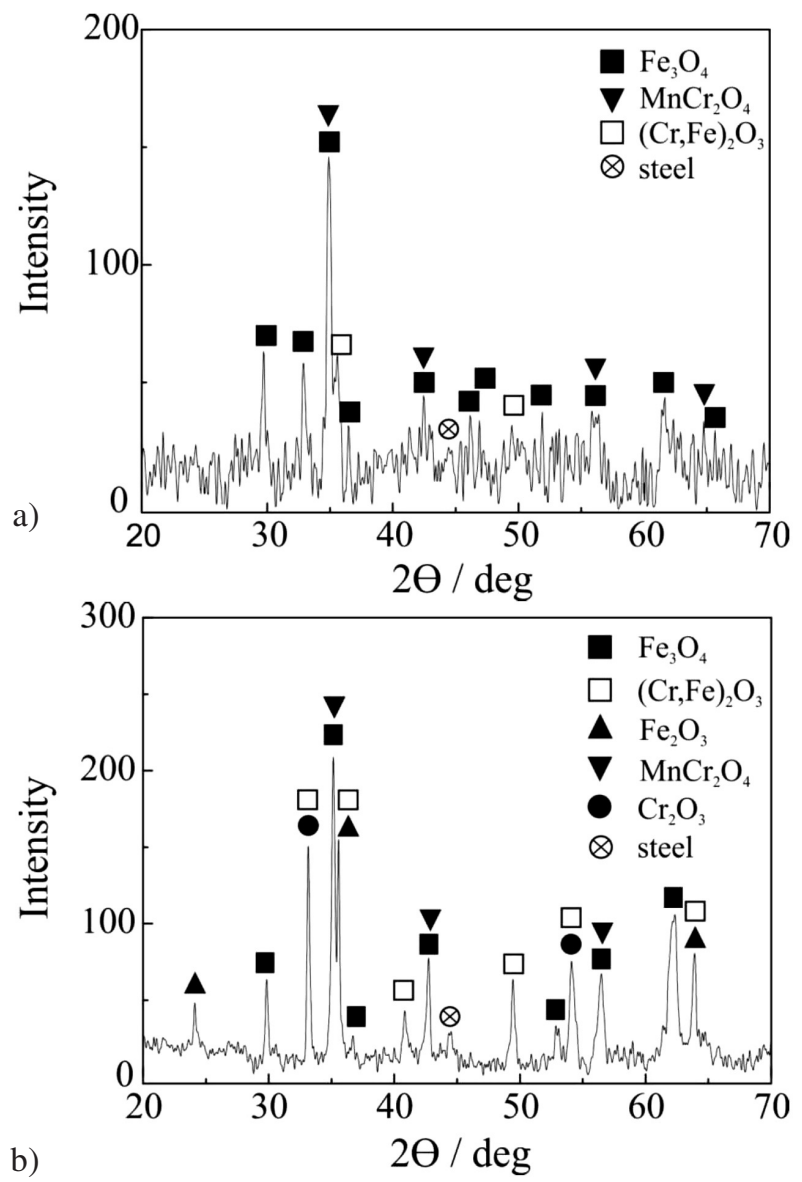

Figure 3: X-ray diffraction patterns for the X50 steel oxidized at $900{ }^{\circ} \mathrm{C}$ in air for $100 \mathrm{~h}$ : a) uncoated steel, b) coated steel materials (with the exception of the X55 steel to some extent). The positive effect of chromium, deposited on the surfaces of the tested steels, is connected with the formation of $\mathrm{Cr}_{2} \mathrm{O}_{3}$ or chromium-containing spinel-oxide phases during the oxidation, instead of iron oxides $\left(\mathrm{Fe}_{3} \mathrm{O}_{4}\right.$ or $\left.\mathrm{Fe}_{2} \mathrm{O}_{3}\right)$, the protective properties of which are much poorer than those of chromium-containing oxides. The influence of a thin chromium layer on the phase composition of the scale is shown in Figure 3, which presents the results of X-ray diffraction of the uncoated and coated X50 steel after the oxidation at $900{ }^{\circ} \mathrm{C}$ for 100 hours.

It should be mentioned that the kinetic results as well as the XRD analysis are in agreement with the morphological observations of the scale grown on the studied materials (Figure 4). It was determined, namely, that the scales formed on the coated and uncoated X33 steel samples are virtually identical (Figures $\mathbf{4 a}, \mathbf{b}$ ) because in both cases, the same fine-grained chromium oxide is present in the scale. This situation results from the fact

(a)

(b)

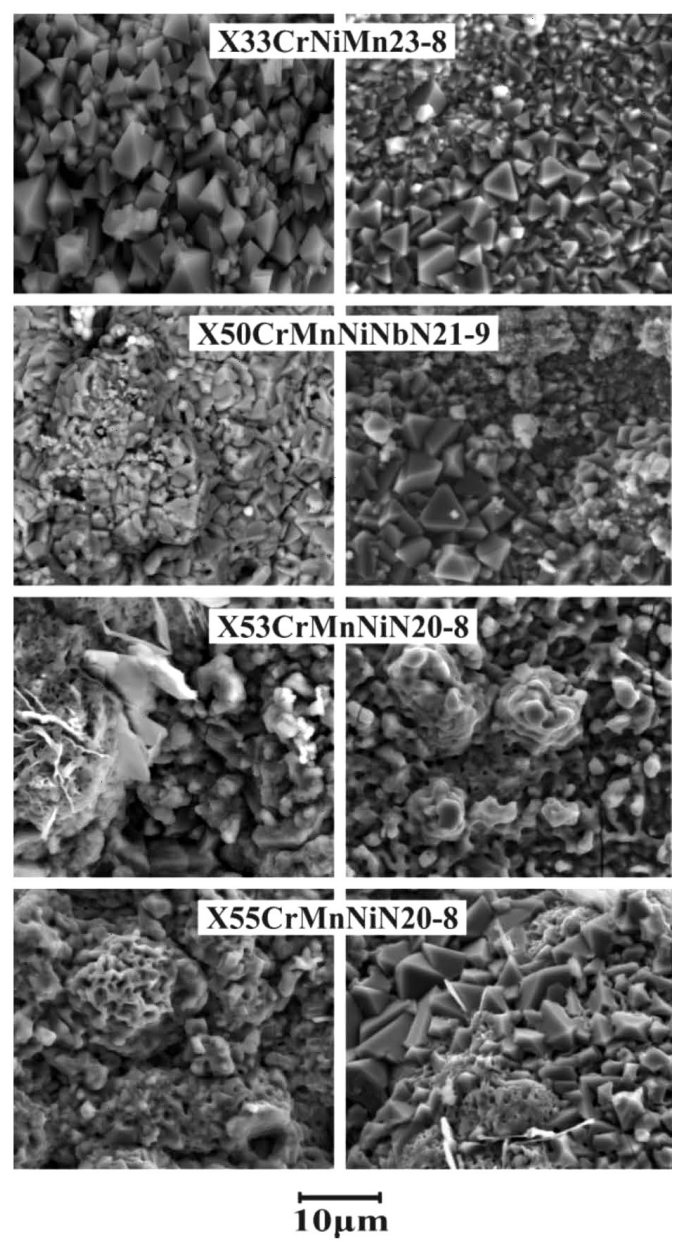

Figure 4: SEM images of the studied steels after the oxidation: a) uncoated X33 steel, b) coated X33 steel, c) uncoated X50 steel, d) coated X50 steel, e) uncoated X53 steel, f) coated X53 steel, g) uncoated X55 steel and h) coated X55 steel 
that the uncoated X33 steel contains enough chromium (Table 1) to form a continuous layer of highly protective chromium oxide. On the other hand, in the case of all the other uncoated steels, unprotective scales are formed, which crack and spall off relatively fast. The adherence of the scales grown on the steels covered with a chromium layer is better. However, the effect of spallation can still be easily observed.

Thus, the obtained results strongly support the main thesis of this work, leading to the statement that it is possible to develop a new generation of high-temperature inexpensive thin chromium coatings for the protection of valve steels against high-temperature oxidation.

\section{CONCLUSIONS}

Thin layers of chromium deposited on the surfaces of the studied valve steels increase the resistance against high-temperature oxidation under isothermal conditions. In the case of the oxidation tests carried out under thermal-shock conditions, an analogous effect was observed, with the exception of the X55 steel, the oxidation resistance of which was not improved. The positive effect of chromium, deposited on the surfaces of the tested steels, is related to the formation of $\mathrm{Cr}_{2} \mathrm{O}_{3}$ or chromium-containing spinel-oxide phases during the oxidation, instead of $\mathrm{Fe}_{3} \mathrm{O}_{4}$ and $\mathrm{Fe}_{2} \mathrm{O}_{3}$. As the protective properties of chromium-rich oxides are much more effective than those of iron oxides, the chromium-coated valve steels underwent a lower degree of degradation than the uncoated materials. It should be noted that the improved oxidation resistance of coated steels is observed during a much longer period than the lifetime of chromium layers, which strongly supports the idea of tailoring a new generation of high-temperature inexpensive coatings for the protection of engine valves.

\section{Acknowledgement}

The investigations presented in this paper were supported by The Ministry of Science and Higher Education through a donation for Young Scientist made with decision no. 15.11.160.018.

\section{REFERENCES}

${ }^{1}$ C. G. Scott, A.T. Riga, H. Hong, The erosion-corrosion of nickelbase diesel engine exhaust valves, Wear, 181-183 (1995), 485-494, doi: 10.1016/0043-1648(95)90162-0
${ }^{2}$ S. Mrowec, T. Weber, Scaling-resistant iron-base alloys in Modern Scaling-Resistant Materials, National Bureau of Standards and National Science Foundation, Washington D.C., 1982, 277

${ }^{3}$ P. Kofstad, Development of stresses and strains, non-protective scales, phase boundary reactions in High Temperature Corrosion, Elsevier Applied Science, London and New York 1988, 278

${ }^{4}$ D. Naumenko, L. Singheiser, W. J. Quadakkers, Oxidation limited life of FeCrAl based alloys during thermal cycling, Proc. EFC Workshop, Frankfurt 1999, 287-306

${ }^{5}$ M. Beukenberg, Thermal Fatigue Evaluation of EB-PVD TBCs with Different Bond Coats, Proc. Turbine Forum, Nice 2006, 26-28

${ }^{6}$ Z. Grzesik, S. Mrowec, Z. Jurasz, K. Adamaszek, The behavior of valve materials utilized in Diesel engines under thermal shock conditions, High Temp. Mater. Proc., 29 (2010), 35-45, doi:10.1515/HTMP.2010.29.1-2.35

${ }^{7}$ Z. Grzesik, G. Smola, K. Adamaszek, Z. Jurasz, S. Mrowec, High temperature corrosion of valve steels in combustion gases of petrol containing ethanol addition, Corros. Sci., 77 (2013), 369-374, doi:10.1016/j.corsci.2013.08.030

${ }^{8}$ Z. Grzesik, G. Smola, K. Adamaszek, Z. Jurasz, S. Mrowec, Thermal shock corrosion of valve steels utilized in automobile industry, Oxid. Met., 80 (2013), 147-159, doi:10.1007/s11085-013-9363-5

${ }^{9}$ R. Gilbert, A. Perl, Energy and transport futures, A report prepared for national round table on the environment and the economy, Univ. Calgary, 2005, 1-96

${ }^{10}$ D. G. Kessel, Global warming - facts, assessment, countermeasures, J. Pet. Sci. Eng., 26 (2000), 157-168

${ }^{11}$ C. N. Hamelinck, A. P. C. Faaij, Outlook for advanced biofuels, Energy Policy, 34 (2006), 3268-3283, doi:10.1016/j.enpol.2005. 06.012

${ }^{12}$ A. S. M. A. Haseeb, M. A. Fazal, M. I. Jahirul, H. H. Masjuki, Compatibility of automotive materials in biodiesel: a review, Fuel, 90 (2011), 922-931, doi:10.1016/j.fuel.2010.10.042

${ }^{13}$ Z. W. Yu, X. L. Xu, Failure analysis and metallurgical investigation of diesel engine exhaust valves, Eng. Fail. Anal., 13 (2006), 673-682, doi:10.1016/j.engfailanal.2004.10.018

${ }^{14}$ B. Gleeson, High-Temperature Corrosion of Metallic Alloys and Coatings, Materials Science and Technology, Wiley-VCH, Weinheim-New York-Chichester-Brisbane-Singapore-Toronto 2000, 174-228

${ }^{15}$ H. Xu, H. Guo, S. Gong, Thermal barrier coatings in Developments in High-Temperature Corrosion and Protection of Materials, Woodhead Publishing in Materials, Cambridge 2008, 476-491

${ }^{16}$ H. E. Evans, High Temperature Coatings: Protection and Breakdown in Shreir's Corrosion, $4^{\text {th }}$ ed., Elsevier Ltd., Amsterdam 2010, 691-724

${ }^{17}$ K. Adamaszek, Z. Jurasz, L. Swadzba, Z. Grzesik, S. Mrowec, The influence of hybrid coatings on scaling-resistant properties of X33CrNiMn23-8 steel, High Temp. Mater. Proc., 26 (2007), 115-122, doi:10.1515/HTMP.2007.26.2.115

${ }^{18}$ D. Dulińska, W. Pawlak, Z. Grzesik, The prospects in designing new generation of high temperature coatings in automobile engines, Arch. Metall. Mater., 60 (2015), 903-907, doi:10.1515/amm-2015-0227

${ }^{19}$ Z. Grzesik, M. Migdalska, S. Mrowec, The influence of yttrium on high temperature oxidation of valve steels, High Temp. Mater. Proc., 34 (2015), 115-121, doi:10.1515/htmp-2014-0023 